ROCZNIKI PEDAGOGICZNE

Tom 12(48), numer $3-2020$

DOI: https://doi.org/10.18290/rped20123-1

YOCHEVED YORKOVSKY

\title{
FROM GREEN-CAMPUS CAMPAIGN INTERVENTION TO ENVIRONMENTAL EDUCATION IN A TEACHING COLLEGE
}

\section{INTRODUCTION}

The global environmental crisis is a burning issue with worries over global warming, air, water and land pollution, loss of forrest areas and more, becoming more evident and relevant than ever before (Patrick et al., 2019). Despite the immediate threat, the awareness and attitudes of individuals and groups toward the issue vary dramatically with many being unaware of the issue or underestimating its importance or magnitude (Gifford \& Nilson, 2014). One of the main tools of coping with this challenge is EE (Environmental Education).

EE is a complex process that helps individuals to learn about the environment. It is focusing in acquiring knowledge of the environment, developing awareness of environmental damage, developing positive attitudes towards the environment, acquisition of action skills, problem solving and developing Pro-EB (Environmental Behavior) (Lederman, 2007). But which EE programs are effective? the study presented herein examined the effectiveness of a green-campus campaign EE intervention carried out in a teaching college in northern Israel.

The green-campus campaign is a structured intervention that is required of any educational institution seeking green-campus certification. The precertification process included sustainable-management implementation and a green-campus campaign (that will be described in more detail later). Implementation of sustainable-management included minimizing resource and energy consumption, reducing waste production and recycling, and the

Dr. Yocheved Yorkovsky-Chair of the Green Council and Health Committee, Gordon College of Education, Israel; address for correspondence: e-mail: yochyork@gordon.ac.il. 
campaign intervention included implementation of formal and informal EE programs promoting environmental knowledge, support pro-environmental attitudes and behaviors (for details, see "Methods"). The goal of exposing preservice teachers to the green-campus campaign was to make them aware of environmental issues and to enhance their pro-EB and their attitude toward the importance of EE. These teachers will be the educators of the coming generations, and thus they have an important role in promoting the green agenda to their students and to the community, namely, to raise a generation of environmentally literate citizens who behave in a pro-environmental manner.

This paper summarizes the results of a study accompanying the implementation of the green-campus campaign EE intervention at the college, utilizing a variety of pedagogical approches. The study examined whether exposing preservice teachers to the campaign made a difference in their knowledge, pro-EB, and attitude toward EE.

\section{THEORETICAL BACKGROUND}

\section{Green Campus}

Higher education (HE) institutions are important in building a sustainable future both globally and locally (Kang \& Xu, 2018). These institutions train future leaders and decision makers who can influence pro-EB (Calder \& Clugston, 2003; Tilbury \& Wortman, 2008). Institutions that train future teachers play an especially important role in educating and shaping future citizens of the world (Beckford, 2008; Gavrila, 2016; Shephard, 2010). Providing EE to preservice teachers is vital, especially for those who will teach in primary schools (Tilbury, 1992); because they intervene early in children's lives and their chances of effecting significant change are greater.

The concept of sustainable development in HE was raised in 1992, in Rio de Janeiro, and is mentioned in the "Agenda 21" (UN Conference on Environment and Development, 1992). In this document, EE was described as essential to achieving sustainable development. EE relies on knowledge, skills, attitudes, and actions in formal and informal settings and for all ages. A blueprint for a green campus was conceived at Yale University (1994), it sets a standard for how to green a campus and recommends incorporating EE into all relevant disciplines and making the campus a model of EB through waste reduction, energy efficiency, and sustainable design (Clugston \& Calder, 1999; Heinz Family Foundation, 1995). "The creation of environmentally 
friendly HE institutions can be defined as a process that reduces the environmental impact both within and outside the HE institutions" (Freidenfelds, Kalnins, \& Gusca, 2018, p. 43). Green educational institutions help protect the environment directly and indirectly. Direct effects are reflected in a sustainable-management, and indirect effects stem from formal and informal EE, aimed at students in the institutions and in the community (Boeve-de Pauw \& Petegem, 2011).

In Israel, the green campus is an initiative of the Ministry of Environmental Protection. It was designed to integrate the green agenda in academic programs and institutions. Any campus that meets the criteria set by a committee, which includes representatives of the Ministry of Environmental Protection and academia, is certified as green-campus. The criteria include establishing a green council, sustainable-management, teaching environmental courses, and promoting community green projects.

\section{Pro-Environmental Behavior, Environmental Knowledge, Pedagogy and What's In Between}

The main goal of EE is to empower students pro-EB. Kollmuss and Agyeman (2002), defined Pro-EB as behavior that seeks to minimize the negative impact of one's actions on the natural and built world. Courtenay-Hall and Rogers (2002) distinguished between direct environmental actions such as recycling, driving less, and buying organic food, and indirect environmental actions such as donating money, political activism, educational outreach, and environmental writing. Finger (1994) noted three types of pro-environmental activism: standard EB (doing at least one of the following: recycling, using public transportation, etc., and trying to learn more about the environment), limited activism (doing the above plus at least one of the following: voting for candidates who are committed to the environment, trying to inform others, signing petitions in favor of environmental protection, and engaging locally to protect the environment), and protest behavior (doing the above plus at least one of the following: sometimes engaging at a local level, opposing projects that destroy the environment, and participating in public demonstrations for the environment). Stern (2000) revealed three factors of behavioral intentions: consumer behaviors (e.g., buying organic products, avoiding purchases from companies that harm the environment), environmental citizenship (e.g., voting, writing to government officials), and policy support, expressed as a willingness to sacrifice economically to protect the environment (e.g., by paying much higher taxes or prices). 
The traditional assumption in EE was that as human beings become more knowledgeable about the environments issues, they will become more aware of the problems and thus be more motivated to act responsibly toward the environment (Hungerford \& Volk, 1990). According to this model, increased knowledge leads to favorable attitudes, which in turn lead to responsible EB. Others viewed this model as too simplistic and argue that the causes of proEB are more complex since some people have difficulty translating their knowledge into pro-EB (Boeve-de Pauw \& Van Petegem, 2011; Carmi, Arnon, \& Orion, 2015; Courtenay-Hall \& Rogers, 2002). However, most researchers agree that people must have basic knowledge of environmental issues to act pro-environmentally (Jensen \& Schnack, 1997; Too \& Bajracharya, 2015).

The term "environmental knowledge" has two aspects (Zecha, 2010). One is knowledge of the environment and nature and of ecological issues and problems. The second concerns knowledge of how to act in an environmentally friendly way. Coyle (2005) distinguished between deep knowledge of environmental science, such as a complete understanding of basic issues, and knowledge that the public could readily identify of most significant environmental principles and problems. Finger (1994) distinguished between "journalistic knowledge" (knowledge of the state of the environment) and "everyday knowledge" (knowledge of recycling, healthy eating). He noted that both types of knowledge are transmitted primarily through the mass media. As far as knowledge is concerned, Krnel and Naglic (2009) found a connection between science education and EE. Science education is important in developing an understanding of the scientific principles that strengthen environmental issues.

The main objective of the pedagogical approaches in EE is to encourage learning for taking positive action toward the environment i.e., empowering students EB (Eames et al, 2006). A great variety of pedagogical approaches are utilized in EE. Sauvé (2005) categorized 15 pedagogical approaches, some of which were utilized in this study, and are summarized briefly:

Conservation: Its main aim is to educate for conservation of natural resources and ecological citizenship through environmental management such as recycling, reuse and reduction of consumption. It's a cognitive pragmatic approach.

Problem-solving: Its main aim is to develop pro-EB. It is focused on an environmental problem and designed to develop attitudes and skills to solve it.

Scientific: Its aim is to develop understanding of the environment through scientific educational skills such as: observations, hypotheses and under- 
standing cause-effect relationships. The approach is predominantly a cognitive one: the environment is an object of knowledge and that knowledge is necessary for appropriate decision making.

Place-based: Its aim is to develop a sense of belonging to a specific environment as a pre-condition for a sense of responsibility to it. A better understanding of the environment enables better relations with it and an ability to better intervene. This approach may be involved in community activities.

Sustainability: Its aim is to promote fair existence of the individual in society and the environment, without harm the existence of future generations. It includes social and economic aspects.

The approaches differ in their source of inspiration, in their ways of teaching and in their emphasis on the sub goals. However the categorization is not monolithic, and they may overlap. Programs and interventions of EE may involve several approaches simultaneously (Sauvé, 2005).

\section{Research Aim and Hypotheses}

The aim of this study was to examine the effectiveness and validity of an EE intervention, following the framework of the 'green campus' campaign, improves their knowledge of environmental issues, their pro-EB, and their attitudes toward the importance of EE. In many ways this is a validation study of an educational intervention aimed at modifying learners' knowledge, attitudes and behaviors, following the classic educational agenda and understudied domain of EB.

The research hypotheses posited that after the implementation of the green-campus campaign, (a) students would show awareness of the campaign intervention activities held at the college during the project, (b) students' knowledge of environmental issues would increase, (c) students' reported pro-EB would increase, and (d) students' attitudes toward the importance of EE would be more positive.

\section{METHODS}

\section{Settings and Study Design}

This study was conducted at a teaching college in Israel that is part of the state-mandated training system of teacher training colleges. It is a multicul- 
tural institution, and its students and faculty members represent the ethnic, religious, and cultural groups typical of northern Israel.

The process of greening the campus at the college, toward green-campus certification was conducted according to the national plan set by the ministry of environmental protection and proceed two years. Implementing the program consisted of: 1. Establishing a "green campus council," which included representatives of the administration, faculty, staff, and students. The council assumed responsibility for leading the campaign intervention toward green-campus certification. 2. Implementing a sustainable-management program which included minimizing energy consumption and resources such as paper and water, reducing consumption and recycling. 3. The campaign intervention included formal and informal education programs. The formal EE program included courses on basic environmental issues (listed in Table 1). The main pedagogical approaches that were utilized included: scientific, conservation, place-based, sustainability and problem-solving (for details see theoretical background: pro-EB, etc.). The informal campus-community education involved experiential actions: a green market of donated used items, an Earth Day celebration that involved in a parade on the beach and was accompanied by a lecture on global warming, green days that included watching a relevant film and a panel discussion on environmental issues, an online environmental quiz, and public information posts on environmental issues on the college's website, e-mails, and environmental bulletin board. A variety of 'visible actions' have been implemented in the building, such as: placing bins for waste recycling around the college; environmental bulletin board with articles and content regarding sustainability; slogans for saving water and electricity and about recycling were hanged around the college; condensed water from air conditioners were used for watering the garden.

Informal campus-community education was integrated into the campaign because it involves experiential learning and contributes to developing action competencies (Barth, Godemann, Rieckmann, \& Stoltenberg, 2007; Too, \& Bajracharya, 2015).

\section{Sample and Data Collection}

The sample included preservice teachers from all disciplines attending the college. A total of 542 students in their first to third year of studies completed the presurvey; of these, 385 students, now in their second to fourth year of studies, completed a postsurvey. The samples were $95 \%$ women and $85 \%$ Jewish; $6 \%$ of the pre-intervention and $2 \%$ of the post-intervention 
were Arab, and $9 \%$ of the pre-intervention and $13 \%$ of the post-intervention were Druze. Participants' average age was 27 years pre-intervention $(S D=5.4)$ and 28 years post-intervention $(S D=5.5)$. At pre-intervention, $6 \%$ of the participants took the environmental course, and $29 \%$ did so at post-intervention. The semester-long course, which covered basic concepts and environmental issues (listed in Table 1), lasted 28 academic hours.

\section{Instrument}

To assess the potential outcomes of the green-campus campaign intervention, the following outcomes were measured using surveys completed by participants both pre- and post-intervention: (a) awareness of the campaign at the college, (b) self-reported environmental knowledge, (c) self-reported pro-environmental actions, and (d) attitudes toward the importance of EE. Quantitative surveys are the method of choice in preliminary assessment of intervention impact and outcomes. It allows coverage of relatively large samples while maintaining standardization of questions presented to the participants. In this case it provides better representativeness and reliability than individual interviews for example (Coolican, 2014).

The questionnaire items were formulated based on the activities held in the campus during the process of greening the campus, and on curse syllabus. The preliminary version of the questionnaire was sent to content-experts. The experts graded the items based on relevance and representativeness of the content units required. The final version included 20 items covering the following aspects:

Student awareness: Participants were asked to rate to what extent the college acts for the environment, and to what extent the college is managed in a green manner, on a 5-point Likert scale. Reliability for the two items was high $(\alpha=.85)$.

Another question asked participants whether environmental-protection actions are taken at the college; they could respond "yes" or "no." Those who responded "yes" were asked to describe the actions taken on the campus.

Knowledge: Participants were asked to rate their knowledge of a variety of environmental concepts and phenomena on a 5-point Likert scale. Items were sampled from the educational program; an example is "To what extent do you understand the concept of ecological footprint?" A panel of faculty members proficient in environmental and ecological education reviewed the items and ranked them for relevance and phrasing. The final 13 items included in the survey were agreed upon by the entire panel. 
Pro-environmental actions: Participants were asked to rate their environmental activity on a 5-point Likert scale and to report their "pro-environment" behaviors on a semi-open item: whether they generally act proenvironmentally daily. Those who responded "yes" were asked to describe in their own words the actions they take to protect the environment.

Attitudes toward EE: Participants were asked to rate the importance of EE using a 5-point Likert scale. An example item is "To what extent do you think it is important to teach EE in school?" The five-item scale was designed by the author and content-validated by a panel of five content-matter experts who reviewed the items and rated them for relevance and clarity.

Demographic information: This was collected from participants and included gender, age, and year of study in the college.

\section{RESULTS}

\section{Program Awareness Check}

Participants were asked to report their awareness of activities related to the green-campus campaign taking place on campus. The findings were analyzed using a $t$ test for independent samples to compare averages. Findings showed a significant increase $(p<.001)$ in student assessment of the green actions at the college after the campaign intervention (pre-intervention: $M=2.62, S D=0.92$; post-intervention: $M=3.97, S D=0.86$ ).

Participants were also asked whether environmental-protection actions were taking place in the college, at pre- and post-intervention. The findings were analysed with a chi-square test for independence. The results showed an increase of nearly 3.5 times the number of students who noted the greencampus actions $(75.4 \%$ post-intervention vs. $21.8 \%$ pre-intervention, $p<.001$; see Figure 1). Students who answered "yes" were asked to list the environmental actions they noticed having occurred in the college (see Table 1). A significant increase was found a in students' notice of recycling, Earth Day, publications, green day, green market, and courses. 
Figure 1. Are environmental-protection actions taking place in the college?

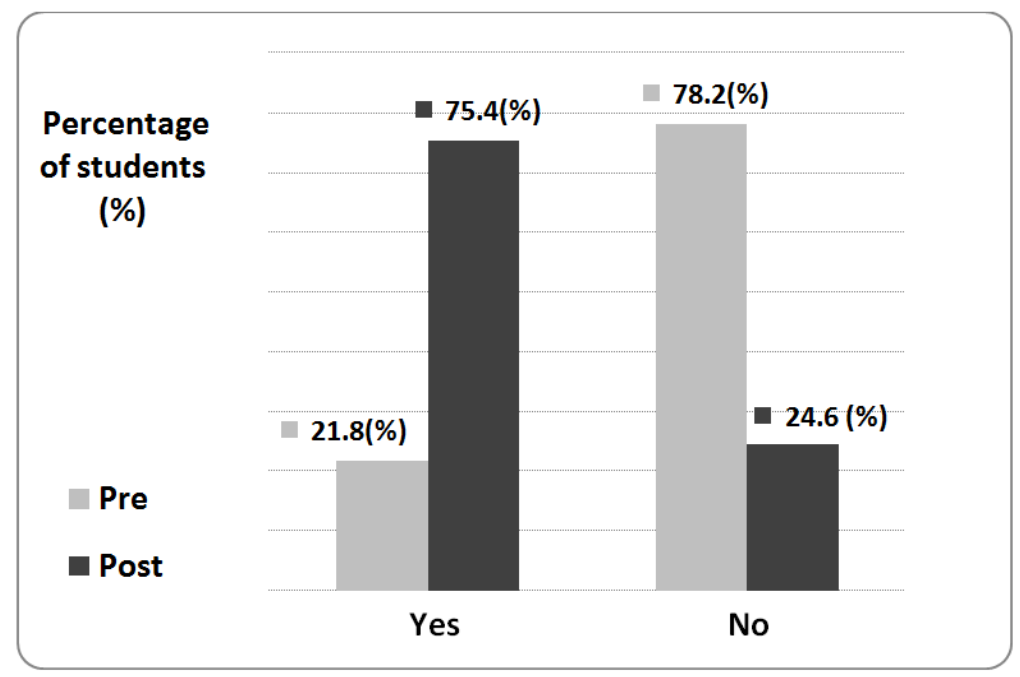

Table 1. Green Actions Noticed by the Students

\begin{tabular}{lcccccc}
\hline & \multicolumn{2}{c}{ Pre intervention } & & \multicolumn{2}{c}{ Post intervention } & \\
\cline { 2 - 3 } \cline { 5 - 7 } Green action & $\begin{array}{c}\text { Frequency } \\
(N=543)\end{array}$ & $\begin{array}{c}\text { Percentage } \\
(\%)\end{array}$ & & $\begin{array}{c}\text { Frequency } \\
(N=388)\end{array}$ & $\begin{array}{c}\text { Percentage } \\
(\%)\end{array}$ & Sig. \\
\hline Recycling & 53 & 9.8 & & 123 & 31.7 & $\chi^{2}(1)=71.06^{* * *}$ \\
Earth Day & 0 & 0 & & 16 & 4.1 & $\chi^{2}(1)=22.79 * * *$ \\
Publication & 0 & 0 & & 16 & 4.1 & $\chi^{2}(1)=22.79 * * *$ \\
Green day & 0 & 0 & & 12 & 3.1 & $\chi^{2}(1)=17.01 * * *$ \\
Green market & 0 & 0 & & 12 & 3.1 & $\chi^{2}(1)=17.01 * * *$ \\
Courses & 8 & 1.5 & & 16 & 4.1 & $\chi^{2}(1)=6.33^{*}$ \\
\hline
\end{tabular}

$* p<.05 ; * * * p<.001$

\section{Knowledge}

Participants' knowledge of environmental concepts and phenomena at preand post-intervention was tested with questions such as "To what extent do you understand the concept of ecological footprint?" Findings were analyzed using a $t$ test for independent samples to compare averages (see Table 2) and 
found a significant increase in reporting on the understanding of education for sustainability, ecological footprint, global warming, sustainable development, return, reduced consumption, biodiversity conservation, and reuse. In contrast, no significant changes were found for the ozone hole, global warming, endangered species, recycling, and environmental protection.

Table 2. Students' Knowledge of Environmental Concepts

\begin{tabular}{|c|c|c|c|c|c|c|c|}
\hline \multirow[b]{2}{*}{ Concept } & \multicolumn{3}{|c|}{ Pre } & \multicolumn{3}{|c|}{ Post } & \multirow[b]{2}{*}{ Sig. } \\
\hline & $N$ & $M$ & $S D$ & $N$ & $M$ & $S D$ & \\
\hline Environmental education & 526 & 2.56 & 1.36 & 374 & 2.91 & 1.32 & $t(898)=3.81^{* * *}$ \\
\hline Ecological foot print & 531 & 2.27 & 1.28 & 375 & 2.59 & 1.23 & $t(904)=3.77 * * *$ \\
\hline Greenhouse effect & 530 & 2.96 & 1.34 & 371 & 3.28 & 1.22 & $t(899)=3.61 * * *$ \\
\hline Sustainable development & 528 & 2.52 & 1.31 & 372 & 2.83 & 1.27 & $t(898)=3.45^{* *}$ \\
\hline Return & 527 & 2.11 & 1.22 & 370 & 2.39 & 1.23 & $t(895)=3.40 * *$ \\
\hline Reduced consumption & 529 & 3.60 & 1.22 & 373 & 3.79 & 1.03 & $\begin{array}{l}t(870.56)= \\
2.59^{*}\end{array}$ \\
\hline Biodiversity conservation & 525 & 2.80 & 1.38 & 372 & 3.01 & 1.36 & $t(895)=2.21^{*}$ \\
\hline Reuse & 532 & 3.61 & 1.21 & 373 & 3.74 & 1.07 & $\begin{array}{l}t(855.00)= \\
1.71^{*}\end{array}$ \\
\hline The ozone hole & 531 & 3.33 & 1.17 & 374 & 3.46 & 1.08 & $t(903)=1.62$ \\
\hline Global warming & 533 & 3.44 & 1.11 & 373 & 3.54 & 1.05 & $t(904)=1.43$ \\
\hline Endangered animals & 533 & 3.75 & 1.10 & 375 & 3.85 & 1.03 & $t(835.49)=1.41$ \\
\hline Recycling & 534 & 3.92 & .93 & 374 & 3.96 & .86 & $t(839.38)=.78$ \\
\hline Environment & 533 & 3.83 & .84 & 375 & 3.83 & .86 & $t(906)=.11$ \\
\hline
\end{tabular}

Note. Likert scale: $1=$ very small extent $;=$ very high extent .

$* p<.05 * * ; p<.01 ; * * * p<.001$.

\section{Pro-Environmental Behavior}

Participants rated their environmental activity at post-intervention $(M=2.82, S D=1.25)$ slightly higher than at pre-intervention $(M=2.59$, $S D=1.25 ; p<.01)$. They were also asked whether they generally act proenvironmentally in their daily life. Answer choices were "yes" and "no." 
Findings reveal that $33.5 \%$ of participants indicated being environmentally active at pre-intervention and $55.0 \%$ at post-intervention (see Figure 2; $\left.\chi^{2}(1)=23.02, p<.001\right)$ increase of about $50 \%$ in the number of participants reporting being environmentally active. Those who answered "yes" were asked to list the environmental actions they take (see Table 3). Significant increase was found only for the response "recycling," which rose from $25.6 \%$ pre-intervention to $47 \%$ post-intervention $\left(\chi^{2}(1)=16.43, p<.001\right)$. There were no significant changes between pre- and post-intervention for the other actions: reduced consumption ( $11.0 \%$ pre- vs. $16.7 \%$ post-intervention), keeping the environment clean ( $11.0 \%$ pre- vs. $16.1 \%$ post-intervention), and EE (33.5\% pre- vs. $29.8 \%$ post-intervention).

Figure 2. Do you take pro-environmental action?

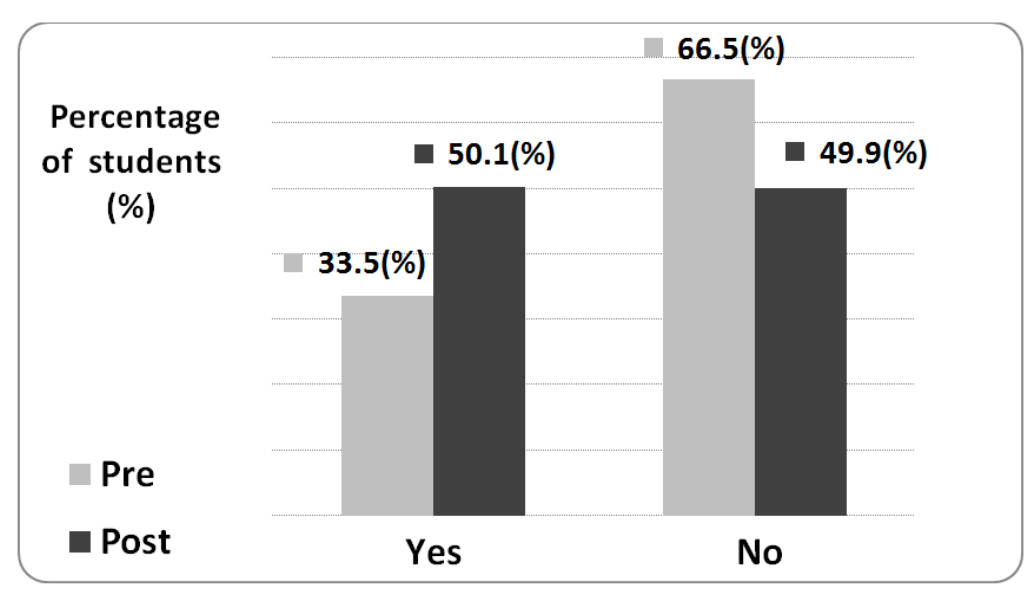

Table 3. Environmental Actions That Students Take

\begin{tabular}{lccccccc}
\hline & \multicolumn{2}{c}{ Pre } & & \multicolumn{2}{c}{ Post } & \\
\cline { 2 - 3 } \cline { 5 - 7 } Activity & $\begin{array}{c}\text { Frequency } \\
(N=146)\end{array}$ & Percentage & & $\begin{array}{c}\text { Frequency } \\
(N=168)\end{array}$ & Percentage & Sig. \\
\hline Recycling & 42 & 25.6 & & 79 & 47.0 & $\chi^{2}(1)=16.43^{* * *}$ \\
Reduced consumption & 18 & 11.0 & & 28 & 16.7 & $\chi^{2}(1)=2.25$ \\
$\begin{array}{l}\text { Keeping the environment } \\
\quad \text { clean }\end{array}$ & 18 & 11.0 & & 27 & 16.1 & $\chi^{2}(1)=1.84$ \\
Environmental education & 55 & 33.5 & 50 & 29.8 & $\chi^{2}(1)=.55$ \\
\hline
\end{tabular}

*** $p<.001$. 


\section{Environmental Education}

Participants were asked to rank the importance of EE (see Table 4). Findings show that they ranked the importance of teaching EE in schools as "high" to "very high" with no difference between pre- and post-intervention. Their rankings for teaching the community, faculty staff, and administrative staff ranged between "moderate" and "high" at pre- and post-intervention. They ranked importance of teaching themselves EE "medium" to "high," with a slight increase at post-intervention $(p<.05)$.

Table 4. The Importance of Environmental Education

\begin{tabular}{|c|c|c|c|c|c|c|c|}
\hline \multirow{2}{*}{$\begin{array}{l}\text { To what extent do you think it } \\
\text { is important to teach } \\
\text { environmental education? }\end{array}$} & \multicolumn{3}{|c|}{ Pre } & \multicolumn{3}{|c|}{ Post } & \multirow[b]{2}{*}{ Sig. } \\
\hline & $N$ & $M$ & $S D$ & $N$ & $M$ & $S D$ & \\
\hline In school & 539 & 4.49 & 0.71 & 383 & 4.48 & 0.68 & $t(920)=.38$ \\
\hline In the community & 535 & 3.92 & 1.02 & 383 & 4.03 & 0.91 & $t(915)=1.51$ \\
\hline $\begin{array}{l}\text { Administrative staff of the } \\
\text { college }\end{array}$ & 537 & 3.73 & 1.13 & 381 & 3.76 & 0.99 & $t(900)=.89$ \\
\hline The faculty & 537 & 3.6 & 1.17 & 382 & 3.71 & 1.01 & $t(900)=1.50$ \\
\hline Students of the college & 541 & 3.4 & 1.21 & 383 & 3.54 & 1.05 & $t(901)=2.03^{*}$ \\
\hline
\end{tabular}

Note. Likert scale: 1 = very small extent; 5 = very high extent.

$* p<.05$.

\section{DISCUSSION}

Education can be a very powerful tool for change. How effective is it within the context of EB? This study tested the effectiveness of EE program, in modifying the perceptions, knowledge, attitudes and behaviors of a sample of teaching students. The green campus EE campaign, implemented in education institutions, especially colleges for education, is potentially an important tool for a sustainable future (Beckford, 2008; Shephard, 2010). Exposing future teachers to such a campaign during a process for green-campus certification may help improve their knowledge of basic environmental issues and enhance their pro-EB and their attitudes regarding the importance 
of EE. These are essential to empowering future teachers and promote an educational ripple effect that may spread the green agenda among their students and in their communities. Until now, there has been too little empirical evidence examining the effectiveness of such interventions. Beyond the immediate outcomes for campuses - how effective are these campaigns as educational instrument of pro-environmental changes? This study examined environmental knowledge attitudes and behaviors of students on campus before and after the intervention.

During the process of greening the camps a set of various 'visible actions' have been implemented on campus. These actions that have higher visibility aspects, can have an educational or behavioural impact that has been framed as "atmospherics" (Cole \& Hamilton 2019; Wu, DiGiacomo, Lenkic, Wong, \& Kingstone, 2016). The findings revealed that most of the participants in this research $(75.4 \%$ post vs. $21.8 \%$ pre $)$ noticed that the college operates in a more sustainable manner (a nearly 3.5-fold increase). This finding, which shows that participants were aware of the activities held in campus is very important, as it demonstrates that the students were exposed to the campaign intervention, and that the other findings can be related to this exposure. Students noticed especially the actions of recycling, Earth Day activities, publications, green day, green market, and courses. These activities are based on the pedagogical approaches of conversation, placebased and sustainability. Thus, it is recommended to integrate them in educational institutions, since they can serve as an informal EE tool in which students and staff can learn about sustainability outside of formal educational settings, and because these activities may serve as modelling activities for the preservice teachers.

Most researchers agree that people need basic knowledge of environmental issues to act pro-environmentally (Boeve-de Pauw \& Van Petegem, 2011; Jensen \& Schnack, 1997). Therefore, during the green-campus project, formal education programs aimed at providing basic environmental knowledge was incorporated into the intervention. The main pedagogical approaches that were utilized included: scientific, conservation, place-based, sustainability and problem-solving (see methods). Students' knowledge of basic concepts and issues regarding the environment was examined according to their self-report, before and after the campaign intervention. The findings showed a significant increase in reported understanding of the following concepts and phenomena: ecological footprint, global warming, sustainable development, return, reduced consumption, biodiversity conservation, educa- 
tion for sustainability and reuse. However, there were no significant changes in reported understanding of the ozone hole, global warming, endangered species, recycling, and environmental protection. The difference between the first concepts - which show improved knowledge - and the others may exist because the former are often unknown to the public whereas the latter are better known because of the mass media. The Israeli media, occasionally, addresses environmental issues, and exposure to the theme may influences environmental knowledge (Baytak, 2011; Bögeholz, 2006; Burgess, Harrison, \& Filius, 1998; Pe'er, Goldman, \& Yavetz, 2007). Hence, for the former subjects, knowledge may improved because of the campaign intervention, whereas the others may have been already known. An interesting finding was the difference in knowledge between two related concepts: the greenhouse effect and global warming. Whereas the former showed a significant improvement in knowledge, the latter did not. A similar result emerged in comparing the two related concepts conservation of biological diversity and endangered animals; only for the former did knowledge improved. The reason for this, here too, may be differences caused by the latter concept being familiar to the public from the mass media whereas the former is usually taught in formally. Improving basic knowledge of environmental issues is essential to developing preservice teachers' awareness as a step that may improve their EB.

One goal of greening campuses (Clugston \& Calder, 1999; Heinz, 1995) is to strengthen the pro-EB of students: they are most likely to beome future leaders, influencers, and educators of the next generation (Beckford, 2008; Ozturk, 2009). Findings indicate a significant increase of about $50 \%$ in the number of students indicating that they act to protect the environment (33.5\% pre- vs. $50 \%$ post-intervention). However, the inrervention was only effective in some concepts examined, such as recycling-a basic pro-environmental activity, that is relatively easy to perform and requires no major change in lifestyle (Finger, 1994) compared to reduced consumption, keeping the environment clean and environmental education.

An interesting finding is that $29.8 \%$ of the students at post-intervention reported being engaged in EE whereas $33.5 \%$ indicated being engaged at pre-intervention. Perhaps the reason for this decline is that the campaign which empowered their knowledge and awareness over time, made the students realize and able to admit that they are not doing enough. From examining the importance that students assign to EE in the community, in schools and for the college staff, there was not a significant change between pre- and 
post-intervention. However, the students rated the importance of EE for themselves significantly higher post-intervention. The difference in students' attitudes towards EE for different target audience may be a result of their personal experience during the campaign intervention. The improvement in their knowledge allowed them to assign specific importance to EE for the target audience they represent. This may be because it is more difficult to change general attitudes, while it is easier to change specific ones, especially, after self-experience (Pelinka, 2017).

\section{RESEARCH LIMITATIONS}

One limitation of this study is that students' knowledge was measured based on self-reported understanding of a concept or a phenomenon and not by an objective test. However, because the results are related to the comparison between their knowledge levels pre- and post-intervention, there can be a mutual offset of subjective effects, making the results more reliable.

The students in this study were exposed to a variety of activities during the campaign intervention and a variety of pedagogical approaches. Some participated in a certain activity while others did not. The impact of a specific activity within the campaign could not be considered, since the large number of students in the study (542 in the presurvey and 385 in the post), and the various activities. Nevertheless, most of the participants in this study were exposed to the 'green-atmosphere' on campus, therefore, the findings are related to the general changes that the sample undergone during the campaign intervention.

\section{CONCLUSIONS}

This study showed small improvements in the knowledge and pro-EB of preservice teachers during a green-campus campaign intervention. Although small, these improvements are important, and they justify continued implementation of a green-campus campaign intervention, that involves varios pedagogical approaches, in teacher training colleges, to enhance preservice teachers' environmental knowledge, awareness, attitudes, skills, and behaviors (Metin, 2010). However, there is a need for more research into how EE might be better integrated into preservice teachers training, and what are the 
best pedagogical approaches that can motivate students. These preservice teachers will educate the coming generations; thus, they play an important role in promoting the green agenda to their students and to the community, namely, to raise a generation of environmentally literate citizens who behave in a pro-environmental manner.

\section{REFERENCES}

Barth, M., Godemann, J., Rieckmann, M., \& Stoltenberg, U. (2007). Developing key competencies for sustainable development in higher education. International Journal of Sustainability in Higher Education, 8(4), 416-430.

BAYTAK, A. (2011). Towards effective instructions in environmental education: A critical review of literature. European Journal of Physics Education, 2(1), 11-15.

BECKFORD, C. (2008). Re-orienting environmental education in teacher education programs in Ontario. Journal of Teaching and Learning, 5(1), 55-66.

Boeve-de Pauw, J., \& Van Petegem, P. (2011). The effect of Flemish eco-schools on student environmental knowledge, attitudes, and affect. International Journal of Science Education, 33(11), 1513-1538.

BöGEHOLZ, S. (2006). Nature experience and its importance for environmental knowledge, values and action: Recent German empirical contributions. Environmental Education Research, $12(1), 65-84$.

Burgess, J., HARrison, C.M., \& Filius, P. (1998). Environmental communication and the cultural politics of environmental citizenship. Environment and Planning A, 30(8), 1445-1460.

Calder, W., \& Clugston, R.M. (2003). Progress toward sustainability in higher education. Environmental Law Reporter News and Analysis, 33(1), 10003-10022.

CARMi, N., ARnOn, S., \& OrION, N. (2015). Transforming environmental knowledge into behavior: The mediating role of environmental emotions. The Journal of Environmental Education, 46(3), 183-201.

Clugston, R.M., \& CAlder, W. (1999). Critical dimensions of sustainability in higher education. Sustainability and University Life, 5, 31-46.

Cole, L.B., \& Hamilton, E.M. (2019). Can a Green School Building Teach? A Pre-and Post-Occupancy Evaluation of a Teaching Green School Building. Environment and Behavior. https:// journals.sagepub.com/doi/10.1177/0013916518825283

Coolican, H. (2014). Research Methods and Statistics in Psychology (6th edition). London: Psychology Press.

Courtenay-Hall, P., \& Rogers, L. (2002). Gaps in mind: Problems in environmental knowledge-behaviour modelling research. Environmental Education Research, 8(3), 283-297.

COYLE, K. (2005). Environmental literacy in America: What ten years of NEETF/Roper research and related studies say about environmental literacy in the U.S. Washington, DC: National Environmental Education and Training Foundation. 
EAmes, C., Law, B., Barker, M., Iles, H., McKenzie, J., \& Williams, P. (2006). Investigating teachers' pedagogical approaches in environmental education that promote students' action competence. Wellington, New Zealand: Teaching \& Learning Research Initiative.

FINGER, M. (1994). From knowledge to action? Exploring the relationships between environmental experiences, learning, and behavior. The Journal of Social Issues, 50(3), 141-160.

Freidenfelds, D., Kalnins, S.N., \& GuSCA, J. (2018). What does environmentally sustainable higher education institution mean? Energy Procedia, 147, 42-47.

GAvrila, M. (2016). Education for Sustainability in University. Exploratory Survey on Desiderata of Italian Teachers and Students. Euromentor Journal, 7(3), 48-58.

GIFFORD, R., \& NiLSSON, A. (2014). Personal and social factors that influence pro-environmental concern and behaviour: A review. International Journal of Psychology, 49(3), 141-157.

Heinz Family Foundation. (1995). Blueprint for a green campus: The Campus Earth Summit initiatives for higher education. Washington, DC: The Foundation.

Hungerford, H.R., \& VOLK, T.L. (1990). Changing learner behavior through environmental education. The Journal of Environmental Education, 21(3), 8-21.

JENSEN, B.B., \& SCHNACK, K. (1997). The action competence approach in environmental education. Environmental Education Research, 3(2), 163-178.

KANG, L., \& XU, L. (2018). Creating Sustainable Universities: Organizational Pathways of Transformation. European Journal of Sustainable Development, 7(4), 339-348.

KAiser, F.G., Wölfing, S., \& Fuhrer, U. (1999). Environmental attitude and ecological behaviour. Journal of Environmental Psychology, 19(1), 1-19.

Kollmuss, A., \& Agyeman, J. (2002). Mind the gap: Why do people act environmentally and what are the barriers to pro-environmental behavior? Environmental Education Research, 8(3), 239-260.

KRNEL, D., \& NAGLIC, S. (2009). Environmental literacy comparison between eco-schools and ordinary schools in Slovenia. Science Education International, 20, 5-24.

Metin, M. (2010). A study on developing a general attitude scale about environmental issues for students in different grade levels. Asia-Pacific Forum on Science Learning and Teaching, 11(2), 1-19.

Lederman, N.G. (2007). Nature of Science: Past, Present, and Future. In: S.K. Abell, and N.G. LeDERMAN, (Eds.), Handbook of Research on Science Education (p. 831-879). Mahwah, NJ: Lawrence Erlbaum Associates.

Pe'ER, S., Goldman, D., \& Yavetz, B. (2007). Environmental literacy in teacher training: Attitudes, knowledge, and environmental behavior of beginning students. The Journal of Environmental Education, 39(1), 45-59.

Pelinka, A. (2017). Attitude change: the competing views. New York: Routledge.

Patrick, L., Solecki, W., Gornitz, V.M., Orton, P., \& Blumberg, A. (2019). New York City Panel on Climate Change 2019 Report Chapter 5: Mapping Climate Risk.

SAuvé, L. (2005). Currents in Environmental Education: Mapping a Complex and Evolving Pedagogical Field. Canadian Journal of Environmental Education, 10(1), 11-37.

SHEPHARD, K. (2010). Higher education's role in "education for sustainability." Australian Universities' Review, 52(1), 13-22.

STERN, P.C. (2000). New environmental theories: Toward a coherent theory of environmentally significant behavior. Journal of Social Issues, 56(3), 407-424. 
TILBURY, D. (1992). Environmental education within pre-service teacher education: The priority of priorities. International Journal of Environmental Education and Information, 11(4), 267-80.

Tilbury, D., \& Wortman, D. (2008). Education for sustainability in further and higher education. Planning for Higher Education, 36(4), 5-16.

ToO, L., \& BAJRACHARYA, B. (2015). Sustainable campus: Engaging the community in sustainability. International Journal of Sustainability in Higher Education, 16(1), 57-71.

United Nations Conference on Environment And Development. (1992). Agenda 21, Rio Declaration: Promoting education, public awareness and training. New York, NY: United Nations.

Wu, D.W.L., Digiacomo, A., Lenkic, P.J., Wong, V.K., \& Kingstone, A. (2016). Being in a "green" building elicits "greener" recycling, but not necessarily "better" recycling. PloS one, 11(1). e0145737.doi:10.1371/journal.pone.0145737.

ZECHA, S. (2010). Environmental knowledge, attitudes and actions of Bavarian (southern Germany) and Asturian (northern Spain) adolescents. International Research in Geographical and Environmental Education, 19(3), 227-240.

\title{
FROM GREEN-CAMPUS CAMPAIGN INTERVENTION TO ENVIRONMENTAL EDUCATION IN A TEACHING COLLEGE
}

\author{
SUMMARY
}

The ecological agenda is a burning issue worldwise but awareness and individual behaviors targeted at managing this approaching crisis vary dramatically. Education may play a pivotal role in such processes, but how do we promote pro-environmental behaviour (EB)? This study tested the effectiveness of a campaign intervention, which was conducted as part of a green campus certification process in a teaching college in Israel. The campaign included formal and informal environmental education (EE) interventions. A pre-post survey assessed students' awareness of the campaign, changes in students' knowledge of environmental issues, pro-EB and attitudes toward EE. The findings showed that students were aware of the interventions held on campus, especially of activities which had high visibility. Moreover, improvement in students' basic knowledge and pro-EB were found, as well as improvement in the importance they ascribe to EE. These findings justify continued implementation of such educational interventions on campuses, involving a variety of pedagogical approaches for preservice teachers, who will educate the next generation.

Key words: Green Campus; Environmental Education; Environmental Behavior; Teaching College; Pedagogy.

\section{OD INTERWENCJI W RAMACH KAMPANII „ZIELONY KAMPUS” DO EDUKACJI EKOLOGICZNEJ PROWADZONEJ W KOLEGIUM NAUCZYCIELSKIM}

\section{STRESZCZENIE}

Na całym świecie agenda ekologiczna jest pilną kwestią, ale świadomość i działania poszczególnych osób zarządzających nadchodzącym kryzysem są bardzo zróżnicowane. Edukacja może odgrywać kluczową rolę $\mathrm{w}$ takich procesach, ale jak należy promować zachowania proekolo- 
giczne (EB)? Przedstawione badania zweryfikowały skuteczność interwencji w ramach kampanii, która była częścią procesu certyfikacji zielonego kampusu w izraelskim kolegium dla nauczycieli. Kampania obejmowała formalne i nieformalne interwencje z zakresu edukacji ekologicznej (EE). W badaniach przed i po (pre-post) oceniono świadomość studentów na temat kampanii, zmiany w ich wiedzy na temat kwestii związanych z ochroną środowiska, ich zachowania proekologiczne oraz postawy wobec edukacji ekologicznej. Okazało się, że studenci byli świadomi interwencji prowadzonych na terenie kampusu, a zwłaszcza dobrze widocznych działań. Ponadto stwierdzono poprawę w zakresie podstawowej wiedzy studentów i ich zachowań proekologicznych, a także wzrost znaczenia przypisywanego EE. Wyniki te uzasadniają kontynuację takich interwencji edukacyjnych w kampusach z zastosowaniem różnych podejść pedagogicznych w stosunku do przyszłych nauczycieli, którzy będą kształcić następne pokolenia.

Słowa kluczowe: Zielony Kampus; edukacja ekologiczna; zachowania proekologiczne; kolegium dla nauczycieli; pedagogika. 